\title{
PKM Kelompok Tani Cabai di Desa Sea Kecamatan Pineleng Kabupaten Minahasa Provinsi Sulawesi Utara Tentang Pemanfaatan Plant Growth Promoting Rhizobacteria Dan Mikoriza Untuk Meningkatkan Produksi Cabai pada Lahan Sub-Optimal
}

\author{
Susan Marlein Mambu ${ }^{1 *}$, Johanis Pelealu ${ }^{1}$ \\ ${ }^{1}$ Jurusan Biologi, Fakultas Matematika Dan Ilmu Pengetahuan Alam \\ Universitas Sam Ratulangi \\ *Penulis Korespondensi. Email: susan.mambu@unsrat.ac.id
}

\begin{abstract}
ABSTRAK
Cabai merah merupakan salah satu komoditas hortikultura yang penting. Hal ini disebabkan banyaknya manfaat yang dapat dipergunakan untuk berbagai keperluan, baik yang berhubungan dengan kegiatan rumah tangga maupun untuk keperluan lain seperti untuk bahan ramuan obat tradisional, bahan makanan dan minuman serta industri. Tidak hanya itu, secara umum tanaman cabai memiliki kandungan gizi dan vitamin di antaranya, protein, lemak, karbohidrat, kalsium, vitamin A, B1 dan vitamin C. Usaha peningkatan produksi cabai dapat dilakukan dengan cara perbaikan teknik budidaya yang meliputi pemupukan dengan pupuk organik, mikoriza dan penggunaan Plant Growth Promoting Rhizobacteria (PGPR). PGPR mampu mempercepat proses pertumbuhan tanaman melalui percepatan penyerapan unsur hara, memacu pertumbuhan tanaman melalui produksi fitohormon dan sebagai bioprotektan, PGPR melindungi tanaman dari patogen. Program kemitraan ini bertujuan untuk memanfaatkan mikoriza dan PGPR sebagi pemicu pertumbuhan tanaman, yang memicu meningkatkan kandungan bahan organik dan unsur hara dalam tanah, sehingga terjadi perbaikan sifat fisik, kimia dan biologi tanah, yang akhirnya berdampak pada peningkatan produktivitas tanah dan meningkatkan pertumbuhan dan produksi tanaman khususnya tanaman cabai. Metode pelaksanaan kegiatan yaitu metode berbasis kelompok yang dilakukan secara komprehensif meliputi penyuluhan, demonstrasi serta tutorial untuk meningkatkan pengetahuan tentang aplikasi mikoriza dan PGPR. Kegiatan tim PKM dilakukan secara terukur disertai proses monitoring evaluasi untuk mengukur ketercapaian target. Hasil kegiatan pengabdian ini menunjukkan terjadinya peningkatan pengetahuan para petani cabai, yang awalnya sebagian besar petani tersebut kurang mengenal tentang teknik budidaya menggunakan pupuk organik, mikoriza dan penggunaan PGPR. Peningkatan keterampilan juga ditunjukkan oleh para petani cabai, melalui kemampuan membuat formulasi pupuk organik.
\end{abstract}

Kata kunci: Mikoriza, PGPR, Kelompok Tani, Cabai

\section{ABSTRACT}

Red chilies are an important horticultural commodity. This is due to the many benefits that can be used for various purposes, both related to household activities and for other purposes such as for traditional medicinal ingredients, food and beverage ingredients and industry. Not only that, chili plants contain nutrients and vitamins including protein, fat, carbohydrates, calcium, vitamin A, BI and vitamin 
C. To increase chili production can be done by improving cultivation techniques which include the organic fertilizers, mycorrhizae and Plant Growth Promoting Rhizobacteria (PGPR). PGPR is able to accelerate the process of plant growth by accelerating the absorption of nutrients, stimulating plant growth through the production of phytohormones and as a bioprotectant, PGPR protects plants from pathogens. This program aims to utilize mycorrhizal and PGPR as triggers for plant growth, which can increase the content of organic matter and nutrients in the soil, improved the soil physical, chemical and biological properties, which have an impact on increasing soil productivity and increasing plant growth and production. especially the chili plant. The method of implementing activities is a group-based method that is carried out comprehensively including counseling, demonstrations and tutorials to increase knowledge about mycorrhizal and PGPR applications. The results showed an increase in the knowledge of chili farmers, which initially most of the farmers were unfamiliar with cultivation techniques using organic fertilizers, and mycorrhizae-PGPR. The chili farmers also demonstrated skills improvement through the ability to make the organic fertilizer formulations.

\section{Keywords: Mycorrhizae, PGPR, Farmer Groups, Chili}

\section{PENDAHULUAN}

\section{Analisis Situasi}

Dalam proses budidaya, peningkatan produksi tanaman dapat dilakukan secara agronomik yaitu melalui pemupukan. Pemupukan dapat dilakukan dengan menggunakan pupuk anorganik maupun pupuk organik. Pupuk anorganik lebih banyak digunakan dengan alasan lebih cepat dalam penyediaan unsur hara dibandingkan dengan pupuk organik. Penggunaan pupuk anorganik yang terus menerus dapat mengganggu keseimbangan kimia tanah sehingga produktifitas tanah menurun. Pemakaian pupuk kimia secara terus menerus menyebabkan terjadinya residu yang berlebihan dalam tanah. Tumpukan residu pupuk ini dalam tanah akan menjadi racun tanah yang mengakibatkan tanah menjadi sakit. Pada tanah yang sakit ini akan mendorong hilangnya hara tertentu, polusi lingkungan dan rusaknya kondisi alam. Asosiasi tanaman dengan jamur atau yang dikenal dengan istilah mikoriza merupakan suatu interaksi simbiosis mutualisme yang sangat umum terjadi di dunia tumbuhan. Fungi Mikoriza Arbuskular merupakan mikroba fungi akar atau mikroorganisme tanah yang berasosiasi dengan hampir semua jenis tanah dan tanaman, dan mempunyai fungsi sangat besar untuk meningkatkan pertumbuhan tanaman dan memperbaiki agregasi tanah (Warouw dan Kainde, 2010). Selain mikoriza, penggunaan
Plant Growth Promoting Rhizobacteria (PGPR) dapat dijadikan sebagai salah satu cara untuk mengembalikan kesuburan tanah, karena beberapa bakteri dari kelompok PGPR adalah bakteri penambat nitrogen (Biswas et. Al., 2000).

Plant Growth Promoting Rhizobacteria (PGPR) atau Rhizobacteria Pemicu Pertumbuhan Tanaman (RPPT) ialah kelompok mikroorganisme tanah yang menguntungkan. PGPR merupakan golongan bakteri yang hidup dan berkembang dengan baik pada tanah yang kaya akan bahan organik (Compant et al., 2005).

Bakteri ini diketahui aktif mengkolonisasi di daerah akar tanaman dan memiliki 3 peran utama bagi tanaman, yaitu :

(1) sebagai biofertilizer, PGPR mampu mempercepat proses pertumbuhan tanaman melalui percepatan penyerapan unsur hara,

(2) sebagai biostimulan, PGPR dapat memacu pertumbuhan tanaman melalui produksi fitohormon dan

(3) sebagai bioprotektan, PGPR melindungi tanaman dari patogen (Rai, 2006).

Mitra dalam kegiatan pengabdian kepada masyarakat ini adalah kelompok tani cabai di Desa Sea, Kecamatan Pineleng. Kegiatan sosialisasi dan pelatihan pembuatan kombinasi mikoriza-PGPR yang akan diaplikasikan pada lahan cabai ini dimaksudkan untuk memberikan informasi tentang peranan mikoriza-PGPR 
dalam meningkatkan kesuburan tanah dan produksi cabai di lahan suboptimal.

\section{METODE PELAKSANAAN}

\section{Sasaran kegiatan}

Sasaran dalam kegiatan pengabdian kepada masyarakat ini adalah kelompok kelompok tani cabai Desa Sea, Kecamatan Pineleng.

\section{Lokasi kegiatan}

Kegiatan secara umum dilaksanakan di Desa Sea, Kecamatan Pineleng, Kabupaten Minahasa.

\section{Metode yang digunakan :}

Pelaksanaan kegiatan pengabdian ini dilakukan melalui metode ceramah/penyuluhan, tutorial, pelatihan pembuatan kombinasi mikoriza-PGPR, dan diskusi yang dilakukan di lokasi mitra. Adapun rencana kegiatan pengabdian ini adalah sebagai berikut:

1. Tahap persiapan: mempersiapkan panduan sederhana, persiapan alat dan bahan untuk pembuatan kombinasi mikoriza-PGPR.

2. Tahap pelaksanaan:

a. (Metode Ceramah/Penyuluhan):

definisi dan manfaat mikoriza-PGPR sebagai pemicu pertumbuhan tanaman.

b. Pelatihan:

Pembuatan kombinasi mikoriza-PGPR

c. Diskusi

d. Evaluasi:

Mengisi kuesioner untuk mengetahui bagaimana respons para peserta dan pengetahuan mereka tentang materi yang telah diberikan.

Setelah selesai pelatihan dan praktek, maka kemampuan peserta dalam memahami materi pelatihan dapat diukur melalui pengisian lembar evaluasi topik pelatihan. Oleh sebab itu setiap peserta mengisi lembar evaluasi pelatihan sesuai dengan kemampuan mereka. Ada 5 aspek yang dinilai untuk peserta sesuai dengan 5 kriteria dengan selang nilai $1-5$ yaitu $1=$ sangat kurang, $2=$ kurang, $3=$ sedang, $4=$ baik, dan 5 = sangat baik.

\section{HASIL DAN PEMBAHASAN}

Dalam rangka menerapkan prosedur Covid19, yaitu tidak melakukan pengumpulan massa, Tim melakukan penyuluhan dan tutorial PKM dalam 3 tahap, dengan jumlah petani tidak lebih dari 5 orang dalam tiap kegiatan, serta langsung melakukan praktek pada lahan cabai milik kelompok. Berdasarkan hasil penyuluhan, wawancara, tanya jawab dan pengamatan langsung selama kegiatan penyuluhan dan pelatihan berlangsung, kegiatan PKM ini memberikan hasil sebagai berikut:

1. Hasil Penyuluhan

a. Meningkatnya pengetahuan dan keterampilan petani cabai tentang pembuatan kombinasi mikoriza-PGPR.

b. Meningkatnya pengetahuan dan pemahaman petani cabai tentang definisi dan manfaat mikoriza-PGPR sebagai pemicu pertumbuhan tanaman.

2. Hasil Pelatihan

a. Meningkatnya keterampilan petani cabai dalam pembuatan pembuatan kombinasi mikoriza-PGPR.

b. Meningkatnya keterampilan petani cabaidalam mengelola dan menggunakan kombinasi mikoriza-PGPR, yang dapat membantu para petani untuk meningkatkan produksi cabai.

Kegiatan penyuluhan dan praktek pada lahan cabai serta pembuatan kombinasi mikoriza-PGPR dapat dilihat pada Gambar 1. 
Jurnal Pengabdian Multidisiplin

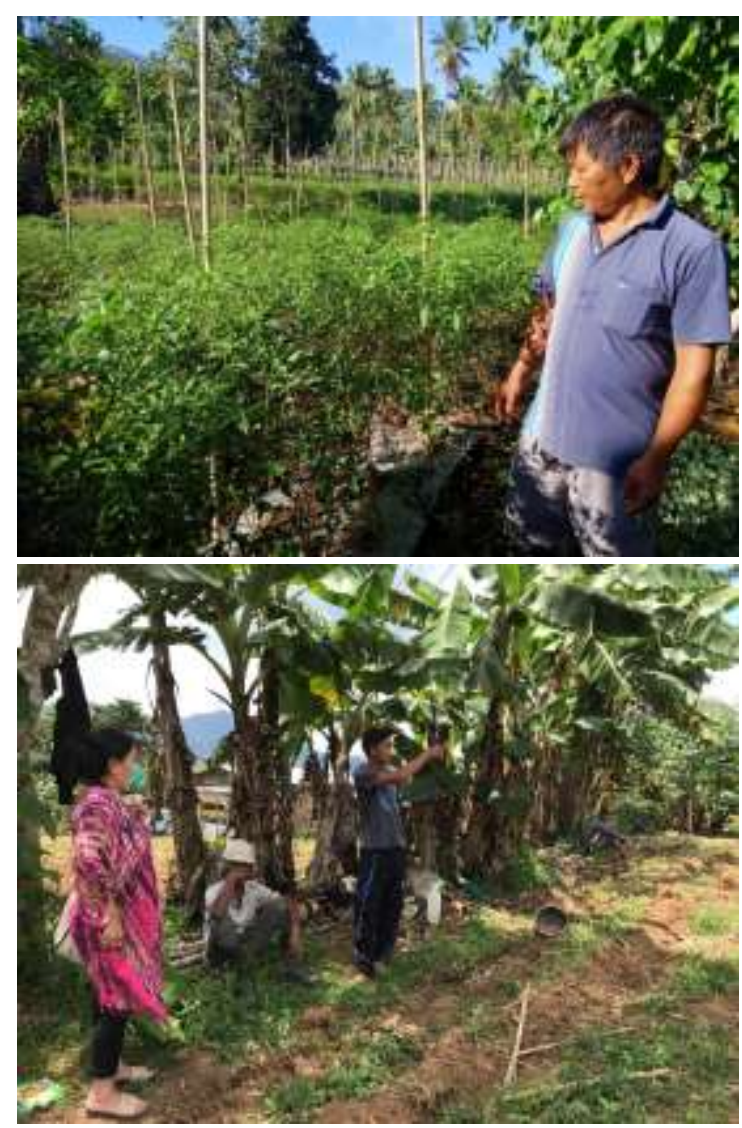

Gambar 1. Dokumentasi Kegiatan Pengabdian

Secara umum, kegiatan pengabdian yang dilakukan memberikan hasil positif. Respons antusias dari pada petani yang mengikuti kegiatan ini menunjukkan hasil yang positif. Para petani cabai umumnya kurang mengenal manfaat mikoriza-PGPR sebagai pemicu pertumbuhan tanaman, dan tidak mengetahui manfaatnya. Hanya beberapa petani yang telah mengetahui jenis dan manfaatnya. Hal ini tampak dari hasil kuesioner awal yang dibagikan sebagai menunjukkan sebagian besar petani cabai belum mengenal apa itu mikoriza-PGPR sebagai pemicu pertumbuhan tanaman. Melalui penyuluhan ini diinformasikan tentang manfaat mikoriza-PGPR sebagai pemicu pertumbuhan tanaman yang dapat dilakukan secara mandiri.

Setelah dilakukan penyuluhan tentang manfaat mikoriza-PGPR sebagai pemicu pertumbuhan tanaman dilanjutkan dengan diskusi. Dari diskusi tersebut, tampak bahwa para petani tersebut sangat senang mendengar informasi ini yang berkaitan dengan usaha peningkatan produksi cabai. Banyak pertanyaan yang diajukan oleh para petani tersebut, antara lain:

- apa yang dimaksud dengan mikorizaPGPR,

- bagaimana dosis tepat pembuatan campuran mikoriza-PGPR,

- apakah kegunaan dari mikoriza-PGPR,

- bagaimana cara kerja mikoriza-PGPR.

Tabel 1. Hasil Rekapan Evaluasi Topik Pelatihan

\begin{tabular}{|c|c|c|c|c|c|}
\hline \multirow[b]{2}{*}{$\frac{4}{\frac{1}{0}}$} & \multicolumn{5}{|c|}{ Total Kriteria } \\
\hline & $\begin{array}{c}\text { Sangat } \\
\text { Kurang } \\
\text { (1) }\end{array}$ & $\begin{array}{c}\text { Kurang } \\
\text { (2) }\end{array}$ & $\begin{array}{c}\text { Sedang } \\
\text { (3) }\end{array}$ & $\begin{array}{c}\text { Baik } \\
\text { (4) }\end{array}$ & $\begin{array}{c}\text { Sangat } \\
\text { Baik } \\
(5)\end{array}$ \\
\hline $\mathrm{A}$ & 0 & 0 & 2 & 4 & 17 \\
\hline B & 0 & 0 & 3 & 3 & 17 \\
\hline $\mathrm{C}$ & 0 & 0 & 1 & 4 & 18 \\
\hline $\mathrm{D}$ & 0 & 0 & 0 & 4 & 19 \\
\hline $\mathrm{E}$ & 0 & 0 & 3 & 3 & 17 \\
\hline
\end{tabular}

Dimana:

A. Motivasi peserta

B. Pemahaman materi

C.Kesesuaian materi pelatihan dengan

kebutuhan peserta

D. Kemampuan peserta mempraktekkan materi pelatihan

E. Kemampuan peserta bekerjasama dalam tim

Para petani cabai juga sangat antusias ketika mengikuti tutorial cara mencampur mikoriza-PGPR sebagai pemicu pertumbuhan tanaman. Metode pembuatan yang sederhana tersebut sangat mudah dipraktikkan di lahan pertanian mereka. Dengan adanya transfer ilmu tentang pentingnya penggunaan mikoriza-PGPR, dapat meningkatkan pengetahuan para petani akan pentingnya mikoriza-PGPR sebagai pemicu pertumbuhan tanaman. Hasil rekapan evaluasi topik pelatihan selama praktek berlangsung, memperlihatkan bahwa tingkat pemahaman petani tentang materi bagaimana cara penggunaan pestisida, ternyata dari 23 orang yang mengikuti praktek, ada 17 orang 


\section{DAFTAR PUSTAKA}

yang mempunyai kategori pemahaman yang sangat baik, 4 orang baik, 2 orang sedang, dan untuk kategori kurang dan sangat kurang tidak ada (Tabel 1). Hal ini di lihat dari keaktifan peserta selama mengikuti praktek. Kegiatan ini juga diharapkan dapat membangun sikap hidup yang positif untuk memulai menggunakan pupuk hayati pada lahan pertanian, sebagai upaya untuk menjaga keberlanjutan lahan pertanian.

\section{KESIMPULAN DAN SARAN}

Program Kemitraan Masyarakat (PKM) untuk memberikan pengetahuan tentang peranan mikoriza-PGPR sebagai pemicu pertumbuhan tanaman kepada kelompok tani cabai di Desa Sea, Kecamatan Pineleng, Kabupaten Minahasa., telah dilakukan dalam bentuk sosialisasi/penyuluhan dan tutorial sederhana bagaimana membuat campuran mikoriza-PGPR. Hasil kegiatan pengabdian ini menunjukkan terjadinya peningkatan pengetahuan para petani cabai tentang manfaat penggunaan mikorizaPGPR, yang awalnya sebagian besar para petani tersebut kurang mengenal dan bahkan ada yang tidak mengetahui tentang apa itu mikorizaPGPR. Peningkatan keterampilan juga ditunjukkan oleh para petani, melalui kemampuan mereka dalam mencampur mikoriza-PGPR dan mengaplikasikan pada lahan cabai.

\section{UCAPAN TERIMAKASIH}

Terima Kasih disampaikan kepada kelompok tani cabai di Desa Sea, Kecamatan Pineleng, Kabupaten Minahasa., yang telah mendukung dan berpartisipasi dalam kegiatan PKM ini. Ucapan terima kasih juga disampaikan kepada LPPM Universitas Sam Ratulangi yang telah mendukung lewat dana kegiatan pengabdian ini melalui skim Program Kemitraan Masyarakat (PKM) Tahun 2020.
Biswas, J.C., Ladha, J.K., Dazzo, F.B., 2000.Rhizobial inoculation improves nutrient uptake and growth of lowland rice. Soil Science Society of America Journal 64, 1644-1650.

Compant, S., Duffy, Nowak, B J., Cle'Ment. C., Barka, E.D.A, 2005. Use of Plant GrowthPromoting Bacteria for Biocontrol of Plant Diseases: Principles, Mechanisms of Action, and Future Prospects. Applied and Environmental Microbiology 72(9), 4951-4959.

Mycorrhizal Fungi in Rhyzosphere of Teak. Eugenia 16 (1), 38-45.

Rai, M. K., 2006. Handbook of Microbial Biofertilizer. Food Production Press. New York

Warouw, V., R.P. Kainde., 2010. Population of Vesicular Arbuscular 